\title{
ALAWITES REBELLION IN SYRIA AGAINST EGYPTIAN RULE (1834-1835)
}

\author{
Mısır Yönetimine Karşı Suriye’de Alevilerin İsyam (1834-1835)
}

\section{Der Aufstand der Aleviten in Syrien gegen die ägyptische Administration (1834-1835)}

\author{
Yousef Hussein OMAR*
}

The history of Alawites in Syria witnessed an important stage, when

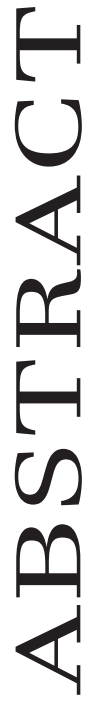
they rebelled against Egyptian rule 1834-1835, after centuries of living under the rule of the Ottoman Empire. This research deals with an introduction to the Alawites and their lives in Syria during the period of Ottoman rule until Muhammad Ali Pasha took control as part of starting a new era of Egyptian rule in Syria in 1832. This research also examines the reasons for the rebellion of the Alawites against the Egyptians in 1834: Disarm, Military Conscription, Cotton Press Machine, and Cutting Down Forests and Trees. The research also deals with the first beginnings of the rebellion and the most important events therein, in addition to the operations of the Alawite rebels in controlling the territories involved including Yunus rebellion, the robberies, the release of prisoners, and the execution of Druze soldiers. This is while also considering the efforts made by the Egyptian authorities to suppress the rebellion. The research also deals with the problem of the selling of Alawites women, the Egyptian reaction to it, and how the Ottomans dealt with the rebellion as a whole. The reasons behind the rebellion's failure have also been discussed. The

Associate Professor (Modern and Contemporary History). Faculty of Arts and Human Sciences, Al-Aqsa University, yhomar73@yahoo.com. 
conclusion addresses the most important results of this research. This research relied on many contemporary Arab documents that recorded the details of the events of the rebellion, in addition to recent references that approach the rebellion through a form of analysis in terms of the circumstances of the rebellion and the reasons for its failure. This research is based on a descriptive historical method and the analytical method as much as possible, which is appropriate for this type of research.

Keywords: Alawites/Nusayris, Egyptian rule, Syria, The Ottoman Empire, Eastern Question. 


\section{ÖZ}

Yüzyıllardır Osmanlı İmparatorluğu'nun egemenliği altında yaşadıktan sonra, Suriye'deki Alevilerin tarihi 1834-1835 yıllarında Mısır yönetimine karşı isyan ettiklerinde önemli bir aşamaya tanıklık etti. Bu çalışmada, 1832'de Suriye'de Misır yönetiminin yeni bir dönemin başlamasının bir parçası olarak Muhammed Ali Paşa'nın kontrolü ele geçirmesine kadar Osmanlı hakimiyeti boyunca Alevilerin ve onların Suriye'deki yaşamları tanıtılmıştır. Aynı zamanda çalışmada 1834 yılında Mısırlılara karşı Alevilerin isyanının nedenleri de incelenmiştir: Silahsızlanma, zorunlu askerlik, pamuk baskı makinesi ve orman ve ağaçların kesilmesi. Çalışma, Yunus isyanı, soygunlar, mahkumların serbest bırakılması ve Dürzi askerlerin infazı gibi Alevi isyancıların toprakların kontrol edilmesindeki operasyonlarına ek olarak isyanın ilk başlangıçlarını ve buradaki en önemli olayları ele almaktadır. Aynı zamanda Mısırlı yetkililerin isyanı bastırmak için sarf ettikleri çabalar da göz önünde bulundurulmaktadır. Çalışmada Alevi kadınların satılması sorunu, Mısır'ın buna tepkisi ve Osmanlıların bu isyanı bir bütün olarak nasıl ele aldığı üzerinde de durulmaktadır. İsyanın başarısızlığının ardındaki nedenler de tartışılmıştır. Sonuç kısmında bu çalışmanın en önemli sonuçları irdelenmiştir. İsyanın koşulları ve başarısızlığının nedenleri açısından bu isyanı analiz eden yeni kaynaklarla birlikte bu çalışma isyanların ayrıntılarını kaydeden pek çok çağdaş Arap belgesine dayanmaktadır. Çalışmada bu tür araştırmalara uygun olarak tarihsel betimleyici yöntem ile birlikte mümkün olduğunca analitik yöntem kullanılmıştır.

Anahtar Kelimeler: Aleviler/Nusayriler, Misır Yönetimi, Suriye, Osmanlı İmparatorluğu, Doğu Sorunu. 


\section{ZUSAMMENFASSUNG}

Nachdem sie jahrhundertelang unter der Herrschaft des Osmanischen Reiches gelebt haben, hat die Geschichte der Aleviten in Syrien in den Jahren von 1834-1835 eine wichtige Etappe bezeugt, als die Aleviten gegen die ägyptische Administration rebelliert haben. In dieser Arbeit wurde das Leben der Aleviten in Syrien vorgestellt, die unter der osmanischen Herrschaft gelebt haben, bis 1832 als Teil der neuen Periode der ägyptischen Administration in Syrien Muhammed Ali Paşa die Kontrolle erlangte. Gleichzeitig wurden in der Arbeit die Ursachen für den Aufstand der Aleviten gegen die Ägypter im Jahr 1834 untersucht: Entwaffnung, Zwangswehrdienst, Baumwoll verarbeitungsmaschinen und das Abholzen von Wäldern und Fällen von Bäumen. Die Arbeit behandelt zusätzlich zu Operationen der alevitischen Rebellen zur Kontrolle der Territorien wie den Yunus-Aufstand, Raubüberfälle, die Entlassung von Gefangenen und die Exekution von drusischen Soldaten, auch die ersten Anfänge des Aufstandes und die diesbezüglich wichtigsten Ereignisse. Gleichzeitig werden auch die Anstrengungen der ägyptischen Verantwortlichen zur Unterdrückung des Aufstandes vor Augen geführt. Die Arbeit erörtert auch das Problem, dass alevitische Frauen verkauft wurden, die Reaktion Ägyptens hierauf und wie die Osmanen auf diesen Aufstand als Ganzes reagierten. Es wurden auch die Gründe hinter dem Scheitern des Aufstandes diskutiert. Im Schlussteil wurden die wichtigsten Ergebnisse dieser Arbeit überprüft. Diese Arbeit basiert sowohl auf den Quellen, die diesen Aufstand aus Sicht seiner Umstände und der Gründe seines Scheiterns analysieren, als auch auf vielen zeitgenössischen arabischen Dokumenten, die die Details der Rebellionen aufgezeichnet haben. Solchen Untersuchungen entsprechend wurde in dieser Arbeit zusammen mit der historisch-beschreibenden Methode soweit möglich die analytische Methode verwendet.

Schlüsselwörter: Aleviten/Nusayris, ägyptische Administration, Syrien, Osmanisches Reich, Nahostkonflikt. 


\section{Introduction about the Alawites and their lives}

Syria fell under the rule of the Ottoman Empire after the defeat of the Mamluks at the battle of Marj Dabiq in 1516 AD (Hathaway, 2008: 39-40; Winter and Levanoni, 2004: 117). The Ottoman Empire was then the seat of the Caliph, the official leader of Sunni Islam and the Caliph of the Prophet Muhammad. He ruled according to Shari'a Islamic law, which are the religious laws derived from the Holy Quran and Hadith tradition of the Prophet Muhammad written down after his death (Y1lmaz, 2018: 1-7; Sowerwine, 2010: 1-14).

This order guaranteed the rights of the religious minorities (Ahl al-dhimmah), which means that Christians and Jews had the right to govern themselves according to the "Millets" system. They were, to a great extent, independent units headed by a religious leader from the community who was responsible for their collective administration and taxation on behalf of the Sultan. This religious tolerance was one of the reasons for the stability of the Ottoman Empire (Ellis, 2018: 4-7). However, the non-Sunni religious sectarian minorities within the state were not recognized as Millets including Shi'a Muslims like the Alawites (the Nusayris), especially since throughout the nineteenth century, the main forms of identity and solidarity between people were their sect, tribe, or city (Worren, 2007: 39-40).

The Alawites mainly lived on the Mediterranean coast in the provinces of Latakia and Tartus and in the coastal mountain ranges of Jabal Ansariya, which are also called the Alawi Mountains. This mountain range separates the coastal plain from the Syrian interior. There were also Alawite rural communities to the east of the Ansariya Mountains. Given the increased immigration and economic development, Alawites also lived in major cities such as Damascus, Homs, Hama and Aleppo. There were many Alawites from the Arab minority living in northwest Syria, specifically in Alexandretta. Its name became Hatay after its annexation by Turkey in 1939 (Worren, 2007: 43).

The Alawites lived as a religious community within the twelfth tradition of Shi'a Islam. Little is known about Alawite beliefs due to the secrecy on which their beliefs are based. This secrecy is one of the main topics in this sect and they are otherwise not distinctly different from other Syrians, and therefore there is no specific linguistic difference between them and the Sunni Muslim majority, as both speak Arabic. Although the Alawites were considered only to be a religious sect, they can also be 
classified as an ethnic group due to the unclear boundaries between the sects. This is where terms such as Alavis, Shiite or Maroni not only refer to an ethnic or ideological religious identity but also to a region, economic and political system, in addition to a wide cultural group and history (Worren, 2007: 43-6).

The Alawites have never formed independent emirates across their history contrary to their Ismaili (Shiite sect) neighbors and competitors. During their long history, the Alawites have been accused since ancient times of co-operating with the external enemies of Sunni Muslim countries, whether with the Mongols or others (Winter, 1999: 61-2). They have been persecuted throughout history by Sunni Muslims as "apostates" (Worren, 2007: 44). As they were also persecuted by the Ottoman Empire, they had to isolate themselves geographically from the external world in an atmosphere of poverty by staying within their own rural areas and mountains (Pipes, 1990: 164).

The Alawi villages in the mountains were then described as "exceptionally poor", with few rivers and other water resources. However, the lack of fertile soil and severe erosion caused by the torrential rain were among the major problems facing the Alawite community. Despite these circumstances, the Alawites continued to live in the region (Capar, 2013: 20; Olsson, 1998: 201). It is likely that life in the mountains made the Alawis gain distinct characteristics such as a reputation for being a "fierce and unruly" population (Pipes, 1990: 164). Thus, they constituted a threat to the stable life on the cultivated plains (Worren, 2007: 44).

The number of Alawites in Syria is estimated, according to some German sources in 1820 , to be around 80,000 . In another source written in the 1830 s, the population of the Alawites was estimated to total about 69,000. Others stated that the number of Alawites who lived in Syria was between 120,000 and 180,000 (Capar, 2013: 22).

European countries in general and American preachers in particular had a desire to protect and transform specific religious and sectarian minorities. The Alawites became important sectarian representatives regarding their point of view and for the consideration of the Ottomans alike. The Ottoman Empire worked to counter missionary efforts and, at the same time, it worked on the conversion of the Alawites from the Shiite doctrine to the Sunni doctrine (Landwehr, 2018: 48-9). Because "religious identity" had become part of geopolitics, the British and French had always 
denounced the unstable situation of the Alawites under Ottoman rule, especially after they were repeatedly attacked by the successor sect (Landwehr, 2018: 49).

Whatever the case, the Alawite mountain people remained trapped in their ancient structures because of their association with their feudal chiefs. These tribes maintained themselves for centuries under an Ottoman Empire unable to disarm them. Regardless, it worked for a long time in order to try and change the demographic reality present in the Alawite regions in order to tighten its control over them. This is how it had worked when housing the Turkmen and Kurdish tribes in the surrounding areas up until the last couple of years before Egyptian rule (Winter, 1999: 65-72).

\section{Egyptian rule in Syria}

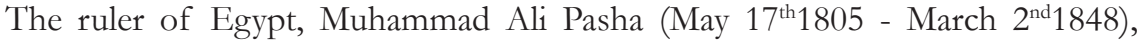
believed that he provided many services to the Ottoman Empire, especially after he eliminated the remains of the Mamluks in the massacre of the Citadel in 1811 and the Wahhabi movement in the Arabian Peninsula in 1811-1818. He tried to suppress the revolution in Morea, Greece in 1821-1827. He therefore asked the Ottoman empire to formally reward him for the what he had provided them, namely by granting him the Wilayat (rule) of the Levant (Syria) along with the state of Egypt for him and his children after him (Shillington, 2005: 1: 782-3). The Ottoman Empire refused this, so Muhammad Ali Pasha decided to achieve his goal through military force. He asked his son Ibrahim Pasha to go to war against the Ottoman Empire. He managed to take over the Levant after defeating the Ottoman Empire more than once (Dodwell, 1931: 108) and in December 1832, Sultan Mahmud II (July $28^{\text {th }} 1808$ - July $1^{\text {st } 1839)}$ sent his last armies. These armies were defeated in Konya on December $21^{\text {st }} 1832$ and the Sultan thus became under the mercy of this rebellious pursuant (Grant and Temperley, 1948: 261). Therefore Muhammad Ali Pasha controlled Syria from that time until 1840 (Shoup, 2018: 81-2) and his son Ibrahim Pasha was appointed ruler (Alkan, 2012, 28).

\section{The reasons behind the Alawite rebellion}

The Egyptians did not face any major armed resistance, despite local protests from a small number of Arabs Sunnis, Druze and Alawites. The locals were subject to Egyptian rule unless the conquest hurt them personally. According to a manuscript 
written by Fathallah bin Antoine al-Sayegh in 1843, a traveler from Aleppo who worked as a translator and guide at the French consulate, the local Syrian Muslims, Christians, Jews and Alawites were tired of the poor Ottoman rule and wanted to change. When they heard during the year 1831 that Ibrahim Pasha was leading an army to invade Syria, they rejoiced and many local leaders began to send messages to teach him the "correct" way to invade different cities, in addition to sending him gifts and food for his soldiers (Talhamy, 2012: 974).

The Egyptian occupation of Syria brought many technical and administrative innovations to Latakia. Mechanical cotton pressing machines were introduced and there was also the professional supervision of the tobacco and wood industry introduced (Winter, 2019, III). The mail network in these areas was merged with the Egyptian Postal Network, and the first modern library in Latakia was established. It was provided with a large number of Arabic books that came from the Bulaq Press in Cairo (Winter, 1999: 63). Alawite girls were prohibited from working as domestic workers. The first Consultative Administrative (Majlis Idāra) administrative council in Latakia was established, and this council exerted great efforts to organize customs related to tobacco, agriculture, military recruitment and more on a non-sectarian basis (Winter, 2019, III).

The Egyptians also reformed the tax system by removing some of the old regulations and imposing new taxes. Muhammad Ali Pasha promised the locals that he would abolish some of the taxes that the Ottomans imposed on them before but the latter did not fulfill this promise. This is because he realized that he needed money, soldiers and workers in order to maintain his authority in the region, especially since it was revealed that the residents from Crete, Adana and Greater Syria were a source of tax revenue, manpower and soldiers for the army. The Egyptians were not satisfied. They imposed new taxes, such as the individual Ferdah, the capital tax and the Baltaz, meaning House Tax. This is in addition to the taxes that the Ottoman Empire imposed: the Miri tax (land tax), the Abscess Kharaj (tax on what the land produces from crops) and more (Talhamy, 2012: 974).

The reforms put in place by the Egyptians reduced the occurrence of repeated bribery, which greatly contributed to securing property and providing security on the roads throughout the country. The reforms also curbed the abuse of power by government officials and prevented unjust punishments (Kinnear, 1841: 331-2). 
In addition, Ibrahim Pasha provided loans and equipment to farmers in order to increase the areas set aside for agriculture and to boost the export of agricultural products. These reform policies got the support of the people in both Syria and Anatolia, meaning that Ibrahim Pasha was initially supported by the population in Syria, including the Alawites (Capar, 2013: 49-50).

Ibrahim Pasha also established, during the Egyptian rule of the Levant, the principle of legal equality for all of his subjects, whether they were Muslim or Christian (Winter, 1999: 63). He raised the Christians up from a state of humiliation and persecution, and gave them freedom in terms of property, stores and assets. They entered a new era of progress and wealth. Ibrahim made the trials and examination of various cases and matters at the hands of councils composed of all sects. The Sunni Muslims in general and the Alawites in particular did not tolerate the progress achieved by the Christians. The extension of the control of the European consuls in their countries worsened to the point where they hated the government of Ibrahim Pasha and the Egyptian rule of their country (Maeruf, 2013, 3: 218).

Therefore the situation did not remain the same as the support for Egyptian rule lessened. Discontent started to become apparent among the Syrians, especially the Alawites, due to the policies of Muhammad Ali Pasha that were in the interests of Christians (Capar, 2013: 49-50). It was said at the time that the Egyptian rule had corrupted the balance that existed between the sects. The sectarianism in Syria, further strained by the distinguished relations between the Eastern Christians and associated European powers, emphasized the silence of Egyptian rule on this (Winter, 1999: 61).

Alawites historians began to divide into two camps:

Made Ibrahim Pasha among the "righteous men of God (Awliya Allah). They praised his justice and equality among the people and how he did not differentiate between religions.

Made Ibrahim Pasha the most evil of God's creations. They portrayed him as a heavenly pest, that his oppression cannot be tolerated by humans (Maeruf, 2013, 3: 217), that he is the worst rebel against the Ottoman Empire (Winter, 1999: 64), and it seems that most of the Alawites were leaning in favor of the anti-Egyptian side. 


\section{Disarm}

Ibrahim Pasha used all of his shrewdness to co-opt the Alawites, yet they did not agree and refused to support him. They betrayed the Ottoman Empire (Altawil, 1924: 390), which prompted him to disarm them, chase them into the mountains, destroy their forts and behead their leaders (Moosa, 1988: 277). This led the leaders of the Syrian society in general and the Alawites in particular to file complaints related to the persecution by Ibrahim Pasha of them to the Ottoman government in Istanbul (Capar, 2013: 50-1).

The Egyptian army began to collect the weapons of the population in Syria. The Egyptians had thus had an awareness of the number of weapons that each town, region and tribe possessed. They expected to collect the numbers that they had estimated. In some areas, the number of weapons collected was lower than the Egyptian government's estimate. People found a solution by buying and delivering weapons to the Egyptian officers in order to protect themselves from punishment and imprisonment in Acre Castle (Talhamy, 2012: 975). The disarmament began to cause unrest, because carrying weapons was normal for the locals, especially for the mountain people, Alawites villagers and others. They used weapons for many purposes, such as hunting, protecting themselves and their villages from attack, and protecting their herds from wild predators (Capar, 2013: 50).

The Alawites' refusal to disarm themselves was one of the reasons for their revolt against Egyptian rule. In 1832, some of the Alawite leaders such as Dahir Saqr al-Mahfuz, the governor of Safita, gathered together a body of armed forces consisting of 3,000 Alawite fighters. They declared themselves loyal to the Ottoman Empire and worked to help take Tripoli back from the Egyptians. However, his assistance was not sufficient at that time to drive the Egyptians out of Tripoli. He failed to prevent the expansion of the Egyptians and their control over Syria where the Egyptian army conducted strong strikes against the rebels. They killed many of them, including Dahir himself (Talhamy, 2012: 981).

The issue of disarmament among the Alawites was considered to be a personal matter and it impacted on a tradition that they had been accustomed to for hundreds of years. It had become part of their civilization and historical heritage. The habit of armament was considered to be normal in a society that was proud to carry weapons as an urgent necessity in their personal life. Given the difficult geographical 
environment in which they lived, being almost completely isolated from the other regions, they had to carry weapons in order to protect themselves, their families and their herds from any dangers that they might face.

\section{Military Conscription}

The policy of the compulsory recruitment under Egyptian rule first appeared when Muhammad Ali Pasha imposed it. This allowed him to build a strong independent army that demonstrated his success on the battlefield. When Syria was granted to Muhammad Ali Pasha after the Treaty of Kütahya on May $4^{\text {th }} 1833$, his son Ibrahim Pasha was ordered to recruit Syrians into the army. The latter was aware of the possible negative reactions to this policy. His father warned him not to do so because the Egyptian regime was newly established in Syria. Treating the population as they had in Egypt would definitely lead to the uprising of the Syrians, yet Muhammad Ali Pasha did not listen to the advice of his son (Marsot, 1984: 235).

Accordingly, Ibrahim Pasha began recruiting all Syrians including the Alawites, Druze, Sunnis and Christians without mercy (Makdisi, 2000: 53). Ibrahim Pasha was the first person to allow the Alawites to join the Egyptian army (Winter, 1999: 63). They treated everyone as if they were "Egyptian peasants" and asked them to obey orders without question or inquiry. This was also without any regard for the conditions of the local population, as he considered that you were either loyal to him or in rebellion against him. There was no compromise. He also warned the locals, "Woe to you, who disobey me" (Makdisi, 2000: 53).

The Alawites in the mountains protested against the forced recruitment, while the Alawites approved and benefited from it along the coast of Syria (Winter, 1999: 63). They also hated the Egyptian procedures for recruiting them. The Syrian recruits were sometimes transferred to the Sudan, to Hejaz and to Egypt, and sometimes to the southern border of Asia. In addition, the recruits never understood what they were fighting for. When the soldiers were victorious during the rule of the Ottoman Empire, they took advantage of that. As for the army under Muhammad Ali Pasha, they were asked to fight against the African Sudanese, the Bedouin Hejaz and against the Ottoman Sultan himself. They did not receive any materialistic or moral benefit as a result of their victories. Moreover, when they had fought before, they returned to their homes for a certain period of time. Under Egyptian rule, they 
worked continuously and were not allowed to visit their homeland and families even in times of peace (Rustum, 1924: 46).

It was clear that there was no system or plan for recruitment for the Egyptians in Syria. The recruitment of the Alawites in particular was usually done by specifying the number of men required for recruitment in each town or village. People are recruited without regard for their age or place. In addition, there was another reason to resist recruitment in mountainous areas: the widespread presence of large families where recruitment meant more poverty and insecure conditions. This was because the families often lost the only person able to support them (Kinnear, 1841: 330).

The Egyptian forces broke into the houses at night and took as many men as possible. Often the mosques themselves were besieged during prayers for the purpose of detaining and recruiting urban youths. Houses were searched from one to the other. Every able citizen was pulled from his bed without distinction in terms of age or personhood, and they were taken to the castle. Here they were imprisoned for forty-eight hours until it was their turn to be examined by European doctors who either accepted them being soldiers or rejected them according to their bodies. Those who had money usually found a way to get rid of the threat of forced military service (Rustum, 1924: 46-7).

This is evidenced by one of the Alawites complaining to Ibrahim Pasha about the policy of compulsory recruitment when he said: "I have three wives and nine children. How can I go? Should I close my house? My God, what do I do? I have three wives and nine children; how I can go? Must I shut my house? Oh God, What am I to do?” (Walpole, 1851, 3: 183)

In addition, the policy of compulsory recruitment for the Alawites harmed the economic situation in those areas, specifically where the region's residents had already been recruited or forced to flee in order to avoid the recruitment. In both cases, the number of economically-active residents decreased which led to a lower production capacity and higher prices on the market (Capar, 2013: 53).

Therefore when the first stage of forced recruitment took place in the Alawite regions, many families fled to the desert or to Cyprus. Hundreds of youths fled to the lands of the Ottoman Sultan Mahmoud II. Many of them also left the cities of central Syria and moved to the mountainous regions (Talhamy, 2011: 29; Rustum, 
1924: 44; Altawil, 1924: 391). The number of those fleeing and leaving their homes and areas in order to avoid forced recruitment during the period of Egyptian rule was estimated to be more than 100,000 people (Talhamy, 2011: 29). As for the remaining young men, they found a solution - specifically by extricating or purifying their eyes or amputating their fingers or hands (Rustum, 1924: 44; Talhamy, 2011: 29; Altawil, 1924: 391).

It was clear that the forced recruitment of Alawites was one of the most important reasons for their rebellion against Egyptian rule in Syria, especially if we take into account the nature of the Alawites who had lived for hundreds of years in remote areas far from the control of the central state. This imposed on them a different reality of living. Their lifestyle believes in freedom and rejects any restriction of the freedom that they are accustomed to. This includes being made to be soldiers in the army that controls their country and serving in it to meet the goals of people who do not belong to their group.

\section{Cotton Press Machine}

The Egyptian army was the first modern organized army in the Middle East, and it was a major consumer of cotton fabrics, especially in wartime. All of Muhammad Ali's wealth in Egypt was based on the state's capitalization of cotton, so one of the first works of Ibrahim Pasha in Latakia was to install mechanical pressing machine in order to mobilize cotton production in western Syria for commercial use or for use in the manufacturing of clothing for the Egyptian soldiers. The Alawites, since the days of the Ottoman Empire, had relied on agriculture and handcrafted market goods for their livelihoods. They were the first victims of this turmoil in the pattern of production as it negatively affected their lifestyle and economic life. In addition, the arrival of military uniforms in a region was a sure indication of the subsequent recruitment of its residents (Winter, 1999: 67).

\section{Cutting Down Forests and Trees}

Deforestation by the Egyptian government also had a role in the revolt of the Alawites (Capar, 2013: 51), where Ibrahim Pasha in Latakia undertook many measures that affected their social status, including the regulation of the rational exploitation of coastal forests by experts specifically tasked with this. Wood was a key resource for the Egyptians which greatly affected the economy of the Alawites. In many of 
their businesses, they depended on logging and selling wood and charcoal (Winter, 1999: 63).

Consequently, it was clear that the economic factor was strongly present alongside the previous factors in the Alawite rebellion against Egyptian rule. It is no less important than the other causes at a time when the economic factor was the main driver of many rebellions around the world.

\section{The start of the Alawite rebellion}

The Alawites rebellion in 1834 was not the first real disobedience against Egyptian rule. Saqr's son Dahir Mahfouz al-Shibli and his forces in 1832 had supported the Ottoman army in a final attempt to stave off Ibrahim Pasha's invasion of Tripoli. Over the course of the following years The Alawite population residing in the mountainous highlands of Latakia was considered to have the best opportunity to end the Egyptian "occupation" of Syria and restore Ottoman sovereignty (Winter, 2015: 60).

The Egyptian authorities again asked the Alawites to hand over their weapons and to allow them to recruit them, but they refused (Talhamy, 2012: 983). They asked the Egyptian authorities to pay the taxes required of them instead, but the Egyptian authorities did not respond to these demands (Talhamy, 2011: 30-1).

This is why the Alawites decided not to abide by the Egyptian decisions regarding their right to flee to the mountains that provided them with a natural refuge from the Egyptian authorities. This prompted the commander of the artillery and Homs Governor Selim Bey to threaten them with the destruction of their homes, vineyards and fields if they continued to resist the policies of disarmament and recruitment. Some Alawites under this threat handed over their weapons but the number of weapons that were handed in and the number of Alawites who abandoned the resistance was not sufficient enough to persuade Selim Bey to stop (Talhamy, 2012: 983).

The Egyptian authorities continued their actions against the Alawites. This led to the declaration of the rebellion in 1834 against the Egyptian rule. The first attack was when 4000 Alawites attacked the Egyptian soldiers marching from Aleppo to Latakia. The attack killed half of the Egyptian soldiers and forced the other half to withdraw to Latakia. Under the influence of this victory, the Alawites attacked 
Latakia itself and managed to storm it. They destroyed the Egyptian government buildings, besieged the home of Mutasallim Antepli Said Agha and later seized it. This was in addition to the rest of the homes. They also laid their hands on the Miri tax money, looted the homes of the Egyptian soldiers (Talhamy, 2012: 982), ransacked the grain stores, and stole horses. The city was affiliated with the Egyptian authorities and the belongings of some women of the Egyptian leaders were taken. Some sources accused the Alawite rebels of looting the patients clothes as they wore them (ENLA, EM, Selim Bey to Ibrahim Pasha, File 249, No. 361, 30 Jumādá al-Ūlá 1250/October 3, 1834).

The Alawite rebels also controlled the headquarters of the Egyptian government in Latakia and the Alawites spread to the markets. Some of them entered and plundered the homes of Christians, which led to fear, flight and hiding in both their homes, and in the ships that were anchored at the time in the port (ENLA, EM, Selim Bey to Ibrahim Pasha, File 249, No. 359, 29 Jumādá al-Ūlá 1250/October 2, 1834). The Alawites were also able to release all of the prisoners in Latakia (ENLA, EM, Haj Muhammad Khalaf Agha to Ibrahim Pasha, File. 250, No. 103, 20 Jumādá al-Ākhirah 1250/October 23, 1834).

The Alawite rebels also gathered in the Qandil Valley region. They violated the sense of security and were subjected to the Egyptian authorities. The fear of the rebels had frustrated Selim's efforts to eliminate them. He had to flee with his relatives to the Kassab area in Antioch at the time to be safe among them and to do what was necessary to defeat them (ENLA, EM, Mahmoud to Unknown person, File. 250, No. 118, 22 Jumādá al-Ākhirah 1250/October 25, 1834). Lt. Col.Yunus Agha, one of the Alawite rebel leaders, was present in the village of Al-Jadaliyya while his forces were present in Qar Sabor, Khan Yu. The people of Bias were also ready to revolt against the Egyptians and that they watching the development of the situation in Antioch and elsewhere to better time their participation in the rebellion (ENLA, EM, Ali Bey and Ibrahim Bey to Selim Pasha, File. 250, No. 152, 27 Jumādá al-Ākhirah 1250/October 30, 1834).

It seems that the Alawite rebellion, since its inception, was characterized by randomness and a lack of organization, in addition to an absence of clear plans or specific leadership. It seems that this matter has shaped the pattern that the rebellion followed from its beginning to end. 


\section{Yunus rebellion and the release of the prisoners}

The Alawite rebels attacked and took control of the Jisr al-Shughur region, stripped their Egyptian leader of power and his soldiers of their weapons. They killed 300 men, destroyed the bridge and took control of Jisr al-Shughur. It was assured that the matter was more than a mere disturbance by the Alawites in this region. At a time when the people in Aleppo and Antep were fed up with what they called the "injustice and tyranny" of Ibrahim Pasha and his men, rumors circulated that Ibrahim Pasha himself had gone missing two or three months ago. No one knew of his whereabouts, so some claimed that he had died. In this position, everyone thought that the powerful Alawites, who were hoping to support the Ottoman Empire, would defeat the Egyptian authorities as soon as the necessary support came to them (Winter, 1999: 65).

Meanwhile, an Alawite named Yunus revolted, sending a warning to the people of the Qusayr region, confirming that the rebels had taken control of Jisr al-Shughur, that the Egyptian soldiers and their allies had been defeated, that half of them had been killed, that Aleppo had been besieged and Idlib had revolted, and that all parts of the country have rebelled against the Egyptian rule. Yunus emphasized that the Minister Muhammad Rashid Pasha was located in the region of Antibes, and that he had direct orders from Muhammad Rashid Pasha to the people of Antioch and the bridge. He was instructed to write to the cities and villages, stating that he who obeys the order of the Ottoman Sultan must be safe. He who refuses obedience makes his livelihood, blood, money and women permissible (Halal). He and the other rebels were declared "jihad for the sake of God" because the Egyptian rulership was invalid (ENLA, EM, Ali Agha Hawari Pasha to Selim Pasha, File. 250, No. 109, 21 Jumādá al-Ākhirah 1250/October 24, 1834).

The Yunus and Alawite rebels crawled into the Al-Fatkia region. His nephew commanded a force of 500 knights and directed them to the Iron Bridge (AlShughur). Muhammad Ali al-Shatorli attacked the village of Al-Deir, while Abd alLatif Agha, the Bayer Region recipient, attacked a group of fighters in the village. The goal of the rebels was to control Antioch. The Egyptian authorities saw that there was a necessity to distribute arms in Antioch to the people to allow them to defend themselves against the rebellion (ENLA, EM, Ali Agha Hawari Pasha to Selim Pasha, File. 250, No. 103, 20 Jumādá al-Ākhirah 1250/October 23, 1834). 
Thus the rebellion of the Alawites spread through large areas such as Latakia, the mountain of the Kurds, Sahion, the Alawites Mountains, Al-Bahluliyya and other important areas (ENLA, EM, Mahmoud to Unknown Person, File. 250, No. 118, 22 Jumādá al-Ākhirah 1250/October 25, 1834).

\section{Egyptian efforts to suppress the rebellion of the Alawites}

Selim Pasha sent a message to Ibrahim Pasha informing him of the Alawite attack on Latakia, in addition to telling him about the initial measures that he had taken to assist the army in Latakia who was tracking the rebels (ENLA, EM, Selim Pasha to Ibrahim Pasha, File. 250, No. 9-11, 2 Jumādá al-Ākhirah 1250/October 5, 1834). Ibrahim Pasha asked his allies in the region to supply him with skilled soldiers with which to fight, especially in the mountainous regions (Winter, 2004: 105). Ibrahim Pasha ordered the commander of the artillery knights, Selim Bey, to lead an Egyptian military force alongside the princes of Mount Lebanon: Prince Khalil son of Prince Bashir Al-Shihabi, Prince Effendi, Prince Jahjah, Prince Saa'd Eddin and Prince Ahmed Bey and their men (Maeruf, 2013, 3: 218; Winter,1999: 62; Winter, 2004: 105). Selim Pasha also involved Aga Putty and Ayoub Bey, commanders of the Elsa infantry group. They moved against the rebellion of the Alawites in Latakia and Selim Pasha expected that the campaign would start either in Jisr al-Shughur or Hama (ENLA, EM, Selim Pasha to Ibrahim Pasha, File. 249, No. 395, 29 Jumādá al-Ūlá 1250/October, 2 1834).

It was clear that the Egyptian authorities intended to deal seriously with the rebellion of the Alawites from the very beginning. This explains the size of the army that the Egyptian army and its allies in Syria had undertaken to gathering in order to eliminate the rebellion in its infancy. This was so then the revolt would not spread to other regions, which might cause harm to the Egyptian rule in this important area of the world.

The Alawites rebels were informed that the Egyptian forces and their allies had come nearer to Latakia. They escaped, and when Selim Bey and the princes arrived with their soldiers, they camped near the village of Al-Bahluliyya (Maeruf, 2012: III, p. 218; Winter, 1999: 62; Talhamy, 2012: 983). Selim Pasha accused the rebels of "rudeness", and said that it was necessary to eliminate them after getting the aid needed (ENLA, EM, Selim Pasha to Ibrahim Pasha, File. 250, No. 52, 12 Jumādá alĀkhirah 1250/October 15, 1834). The Alawites were forced to flee Latakia into the 
mountains (Maeruf, 2012, 3: 218; Winter, 1999: 62; Capar, 2013: 54-5; Talhamy, 2012: 983). As for Selim Bey, Ibrahim Pasha was informed that he had marched into the southern provinces of the Alawites Mountains where he had arrested some rebels. He had killed many of them, led by Ahmed Al-Qarqur, Prince Khalil and Prince Aslan and Taha Katekhda Abdullah Agha. He then walked himself to Latakia to get revenge against the rebels and those who had conspired with them from among the residents (ENLA, EM, Selim Bey to Ibrahim Pasha, File. 249, No. 361, 30 Jumādá alÜlá 1250/October 3, 1834). He proceeded to confiscate the weapons and livestock of the Alawites, in addition to their crops and their belongings as "spoils". They also burned some of the Alawite villages nearby. When Selim Bey sent his soldiers to burn more villages, his forces met the Alawite rebels. They fought and the Egyptian army was defeated. Prince Jahjah walked to them at the head of 1,000 soldiers, defeated the Alawites and burned 30 more Alawite villages (Maeruf, 2012: III, p. 218; Winter, 1999: 62; Talhamy, 2012: 983), in an attempt to prevent other Alawites from thinking of joining the rebels against Egyptian rule (Talhamy, 2012: 983; Capar, 2013: 54-5). However, it was clear that the question of the rebellion in the Alawites Mountains in Latakia was not over, so Ibrahim Pasha decided to make his headquarters in Tripoli due to the existing unrest (ENLA, EM, Ibrahim Pasha to Sami Pasha, File. 250, No. 382-3, 6 Dhū al-Hijjah 1250/April 4, 1835).

The weakness of the organization, the armaments and the planning that characterized the Alawite rebellion, along with the strength of the Egyptian army whose training and armaments was able to compete with the best modern European armies, was a natural and logical reason for its victories over the Alawite revolt. The most difficult thing for the Egyptian army to face was the dispersal of events and their abundance, in addition to the rugged areas in which these rebels lived. This meant that the Egyptian army was facing a guerrilla war and not a regular army in rugged mountainous areas. Perhaps this was the only reason that explained the relative duration of the Alawites rebellion at that time.

\section{Druze Execution}

At first, it was clear that there was an initial alliance between the Druze and the Alawites against Egyptian rule. The two parties were together and the Egyptians dealt with them similarly, so the Druze in the Chouf and Hawran areas revolted strongly against compulsory recruitment. However, the Egyptians did not begin to physically disarm them until after the eradication of the Alawites rebellion in the autumn of 
1835 (Winter, 1999: 65-6)due to the possibility of the Ottoman Empire launching a military campaign against Syria. The possibility of an alliance between the Druze and the Ottoman forces was imminent, so the Egyptian authorities decided at that time not to disarm them in return for recruiting the Druze to serve in the Egyptian army (Capar, 2013: 58).

Nevertheless, it was clear that the Druze were not at the heart of Syria and the Lebanon region where the Druze participated under the flag of the Shiites in the battle against the Alawites in November 1834. As for the Druze in northern Syria, they were subjected to disarmament and recruitment at about the same time as their Alawites neighbors. Although there was some talk about the Druze alliance with the Alawites in the rebellion against the Egyptian rule in 1834, most sources deal with this rebellionas an event mainly confined to the Alawite community (Winter, 1999: 65-6).

Selim Bey sent a message to Selim Pasha stating that Hassan Agha Deli Pasha and Majoon Agassi Paste had arrived near Latakia, and that Druze soldiers were also close to accessing it (ENLA, EM, Selim Pasha to Ibrahim Pasha, File. 250, No. 73, 14 Jumādá al-Ākhirah 1250/October 17, 1834). While Prince Khalil Al-Shihabi went to the rebel areas at the head of 10,000 fighters to cooperate with Major General Selim Bey, the Druze forces had already arrived, despite Selim Bay's complaint that the Egyptian ammunition was low in Latakia (ENLA, EM, Ali Bey and Ibrahim Bey to Ibrahim Pasha, File. 250, No. 140, 145, 148, 156, 160, 25-30 Jumādá al-Ākhirah 1250/October 28- November 2, 1834).

Meanwhile, about a thousand Druze led by Prince Fendi arrived at the castle of Sahion to assist the Egyptian army where they were in touch with the Alawites rebels (ENLA, EM, Selim Bey to Selim Pasha, File. 250, No. 200, 12 Rajab 1250/November 13, 1834). The latter had managed to arrest 500 Druze among Ibrahim Pasha's soldiers in Wadi Al-Ayoun (near the Alawites Mountains), and they slaughtered them on a round rock. To this day, it is called "the Rock of Blood" near Al-Marqab Castle (Maeruf, 2012, 3: 219-20; Altawil, 1924: 390; Capar, 2013: 55-6; Moosa, 1988: 277).

This incident was an indicator of the pessimism becoming present, and it raised many questions related to the ability of the Egyptian army and its allies to suppress the rebellion, despite the success that they had previously achieved. The events also increased the morale of the Alawites after a series of defeats and it pushed them 
to continue the rebellion. This was despite all of the losses they had incurred and despite the balance of power being clearly tilted in favor of the Egyptians.

\section{The efforts of the Egyptians and their allies to suppress the rebellion continues}

Selim Bey sent a message to Ibrahim Pasha telling him that Ibrahim Bey, the commander of the thirteenth cavalry of Alai, had not yet received the order from Selim Pasha that he should move from the place he was in to the area of the rebellion. In compliance with the orders, he should head to the fronts of Tarsus and Safita. He also reaffirmed that he had arrested Ahmad al-Qarqur and executed him along with many Alawite rebel leaders. He had collected more than 400 guns, 100 pistols, 82 daggers and 60 swords from the Alawites. Meanwhile, the people in Al-Bahluliyya, Sahion, the Kurds Mountain and the rest of the region still refused to hand over their weapons. The rescue that was sent to him had arrived which led to the rebels escaping from Latakia (ENLA, EM, Selim Bey to Ibrahim Pasha, File. 250, No. 19, 4 Jumādá al-Ākhirah 1250/October 7, 1834; Maeruf, 2013: III, 218; Capar, 2013: 55; Talhamy, 2012: 983).

While Selim Bey was continuing his military efforts, Aga Putty at the head of 200 horsemen set out from Jisr al-Shughur to Jabal Al-Kuran and Jabal Al-Kalb. This was where he clashed with the Alawites rebels and defeated them, seizing some of their cows and horses (ENLA, EM, Selim Pasha to Ibrahim Pasha, File. 250, No. 51, 11 Jumādá al-Ākhirah 1250/October 14, 1834). It is clear that the control of the cows and horses was the result of controlling the Alawite villages after defeating the Alawite rebels. They were not spoils of the engagement itself, especially since the rebels were staying and traveling in the mountains, in the case of the continuous clashes with the Egyptian authorities. This negated the previous hypothesis about their possession of horses and cows.

Selim Bey also confirmed that he was still undertaking a lot of military measures to completely "put down sedition" in Latakia and Jabal Alawites. This included punishing those who had risen up. He also confirmed that he had marched to AlMarqab Castle to collect weapons from the Alawites and that he collected 3000 rifles and many of the swords, pistols, and daggers from the provinces of Al-Marqab, Qadmous, Al-Khwabi, Sultan Ibrahim and the coastal villages. Some of the Alawites families complied with the order to collect the weapons and whereas others did 
not comply such as in the areas of the people of Bani Ali, Al-Qardaha, Sahion, Al-Bahluliyya, Jabal Al-Kurds and more. The residents of these areas carried out the rebellionin order to prevent this from happening further. After controlling AlMarqab, the Egyptian forces and their allies went to Latakia where they entered and took control. They arrested some of the people who had helped the rebels and participated in looting the Egyptian government, including some of the army (ENLA, EM, Selim Bey to Ibrahim Pasha, File. 250, No. 52, 12 Jumādá al-Ākhirah 1250/October 15, 1834; Maeruf, 2013, 3: 220-1; Capar, 2013: 55).

After that, the people of the Alawites district of Darius surrendered themselves and their weapons to the Egyptian authorities. As for the people of Beit Yashout, Al-Saramtah and Al-Qarahleh, they refused to do so. Prince Bashir Al-Shihabi sent 500 fighters as a reinforcing and helpful force to support the Egyptian army. Out of Bashir al-Shihabi's forces, 36 of them were killed and only 6 men were killed from the Alawites (Maeruf, 2013, 3: 219). Later, Selim Pasha sent another message to Muhammad Ali Pasha to tell him that he had marched from the Jableh region to the area of Al-Saramtah and that the people fled from his face. Their leaders offered obedience to the Egyptians and pledged to carry out their duties towards the Egyptian rule in their respective areas (ENLA, EM, Selim Pasha to Mohammed Ali Pasha, File. 250, No. 506, 22 Dhū al-Hijjah 1250/April 20, 1835; Maeruf, 2013, 3: 227-8).

Prince Khalil, Prince Effendi, Arab al-Hanadi and some of the Egyptian knights went to the village of Jablaya and attacked it. The Alawites rebels fought them and defended themselves fiercely, but the Alawites were eventually defeated. After that, Selim Bey marched his army from Al-Bahluliyya to the province of Sahion where there was a major battle between the Egyptian forces and their allies on the one hand and the Alawites on the other hand. The Alawites were defeated after 15 people were killed while among Prince Khalil's forces, two men were killed. The Egyptian army also attacked the fortress and took control of 3 of its towers. It put 100 soldiers in it to secure the place and to fight the trapped Alawites who were forced at midnight to demand safety for their lives. They were given it but they soon fled from the castle as soon as the Egyptian army entered it (Maeruf, 2013, 3: 218-9; Winter, 1999: 62).

The Egyptian army continued its efforts to suppress the Alawite rebellion, killing 32 leaders of the Alawite rebellion in the regions of Akkar, Safita and Tripoli. A number of Latakia rebels were arrested and imprisoned until they were handed over 
to Selim Bey who then took them to Homs on February $26^{\text {th }} 1835$ (ENLA, EM, Selim Bey to Unknown Person, File. 250, No. 406, 28 Shawwāl 1250/February 26, 1835; Maeruf, 2013, 3: 227).

After things began to settle gradually, the Egyptian army collected the weapons that were possible to collect from the Alawites in the mountains. They collected the backlog of food from them as well but due to the poverty of the provinces of AlBahluliyya and Qardaha, the required amounts were dropped (ENLA, EM, Ayob Sabry Bey to Unknown Person, File. 255, No. 94, 3 Rabī' al-Thānī 1253/July 6, 1837).

The truth is that the Egyptian army and its Druze allies had pursued a scorched earth policy in their dealings with the Alawite rebellion (ENLA, EM, Selim Bey to Ibrahim Pasha, File. 250, No. 238, 27 Rajab 1250/November 28, 1834; Winter, 1999: 62).

This was in order to eliminate the rebellion and to serve as a deterrent to others if they were thinking of a rebellion against Egyptian rule. It was clear that the Egyptian forces and their allies were doing well to get to this point.

\section{Elimination of the rebellion in Qardaha}

Major General Selim Bey emphasized in a letter to Ibrahim Pasha that the Egyptian army's efforts to eliminate the rebellion in Latakia were continuing in the mountains, that the number of guns collected from the Alawites in the Alawites Mountains was more than 5,000 and that the rifles that have not been collected are no more than 3,500 (ENLA, EM, Selim Bey to Ibrahim Pasha, File. 250, No. 238, 27 Rajab 1250/November 28, 1834). The Alawites affiliated with the Qardaha district submitted and demanded safety after their homes were burned and trees cut down. The number of guns they had collected from them only numbered 6800 rifles. Some of the Druze soldiers were infected with smallpox and other diseases, so 700 soldiers were dismissed to return to Lebanon. These orders were issued to the forces confidentially on December $10^{\text {th }} 1834$ (ENLA, EM, Selim Bey to Ibrahim Pasha, File. 250, No. 263, 9Sha'bān 1250/December 10, 1834).

After the signs of the collapse of the resistance of the Alawites rebels became apparent, many of the Alawite leaders, headed by Utman al-Gabbur, went to deal with the issue of the weapons confiscation. Due to the slow pace of the disarmament, the 
Alawite lands continued to be destroyed by the Egyptian army and they ended up completely destroying Qardaha (Winter, 1999: 61-2).

The Alawite revolt against Egyptian rule did not end with the fall of Qardaha. Many local revolts broke out at the end of 1834 in Aleppo, Kilis and Antioch, a border town that was a military base for Ibrahim Pasha.The proof of this is the rebellion led by Küçükalioglu Mustafa - known as the Derebey - against Egyptian rule, where he declared his independence in the Amanos Mountains, and there he defended himself against the Egyptian rule, who worked to subjugate him (Winter, 1999: 66).

\section{Stealing military uniforms}

The Egyptian forces suffered from the issue of transferring military clothes to their forces. At the end of the Alawite Rebellion, specifically on February $8^{\text {th }} 1835$, bandits in Latakia stole the shipments of military clothes that were on their way to the Egyptian army in Latakia (ENLA, EM, Mohammed Sharif Pasha to Mohammed Ali Pasha, File. 250, No. 352, 9 Shawwāl 1250/February 7, 1835). This amounted to 50 or 60 packs. The attack on the caravans was not intended to deliver the message that the results of the Egyptian presence were very costly but instead, to strike against the authority of the Egyptians and the symbol of the Egyptian forces, the army (Winter, 1999: 65-7).

This indicates that the Alawites were not yet ready to accept their defeat at the hands of the Egyptian army and its allies. They sought revenge even in the simplest ways to express this, despite the fact that the Egyptian army had settled the matter.

\section{The selling of Alawite women}

Major General Selim Bey assured Ibrahim Pasha on Rajab 26, 1250 AH that Sheikh Muhammad Al-Mughrabi (who died of plague in 1828) had permitted in 1820 that the families of Alawite children and their women be held captive in Latakia. Selim Bey was not satisfied with this and condemned this act, threatening to punish those who engaged init (ENLA, EM, Selim Bey to Ibrahim Pasha, File. 250, No. 236, 26 Rajab1250/November 27, 1834; Talhamy, 2010: 183). The French consul in Latakia bought an Alawite girl and freed her, and a good number of Alawite women known by name had already been sold to some of the Egyptian army officers. The consul accused Yousef Agha Sharif, the governor of Tripoli and Latakia, of intolerance and 
oppression. He shouldered some of the responsibility for this (ENLA, EM, French Consul in Latakia to Unknown person, File. 255, No. 156, Undated).

Muhammad Ali Pasha sent to his son Ibrahim Pasha to deal with the accusation made by the French consul in Latakia directed to Ayoub Agha Block bashi. Yusuf Agha Sharif was investigated by others. If it was proven that Ayoub Agha and others had actually bought the Alawite girls, they would be executed with the girls returned to their families (ENLA, EM, Mohammed Ali Pasha to Ibrahim Pasha, File. 214, No. 1488, 13 Sha'bān 1253/November 11, 1837).

After the suppression of the Alawite rebellion, the Egyptian authorities were keen to defuse any problem and not to incense the Alawites in any way. They sought to correct the defect and to never repeat it.

\section{How did the Ottomans deal with the rebellion of the Alawites?}

It was known that the Ottoman Sultan Mahmoud II had sent his spies to the areas occupied by Egyptians in Syria, including the areas of the Alawites, not only to collect military information but also to provoke sectarian revolts against the Egyptians. This again raised the issue of Alawites loyalty to the Sultan and the Ottoman Empire (Winter, 1999: 64). It might have been possible for the Ottoman Sultan to easily remove Muhammad Ali Pasha from Syria if he had sent the necessary assistance in 1834 to the residents of Palestine and Syria who were communicating with him for help (Poujoulat, 1841, 2: 349), even if there had been a tendency to overestimate the effective strength of the Alawite rebels. However, it was clear that they represented the best hope for the return of Syria to the Ottoman Empire up until the end of 1834 (Winter, 1999: 68).

Meanwhile, the Ottoman agents were supporting the rebel groups, including the Alawites, in order to weaken the Egyptian rule in Syria and to construct a base to take Syria back. During the clashes between the Alawites and the Egyptians, the agents sent messages to the Alawites in order to encourage them to continue the resistance against the Egyptian rule. They enabled them not to accept the policy of disarmament. The agents also spread rumors that the Ottoman forces would attack Syria soon and regain control of the region again (Capar, 2013: 56; Talhamy, 2011: 31). 
It was clear that the Egyptian authorities were fully aware of the contact between the Alawites and the Ottoman Empire as Selim Pasha was sent to Muhammad Ali Pasha to tell him that some of the Alawites in Aintab, Aleppo and in the mountains were communicating with Muhammad Rashid Pasha. The rebels in the Alawites Mountains might be responsible forthe contact in their area. The recipient, Aintab Hakim Aga, was also accused of this "political crime" due to his relative relationship with Muhammad Pasha Gebatoglu, who was a companion of Muhammad Rashid Pasha (ENLA, EM, Selim Pasha to Mohammed Ali Pasha, File. 250, No. 88, 18 Jumādá al-Ākhirah 1250/October 21, 1834).

In fact, the Ottoman officials exaggerated the impact of the Alawites rebellion on the Egyptian rule. Although the rebellion did not result in the victory of the Alawites, some Ottoman officials considered that the "numerous and powerful" Alawites rebellion was strategic. Perhaps the aim of this "exaggeration" was to fuel the hatred of the people in Syria against the Egyptian rule and to increase their desire to restore Ottoman control (Alkan, 2012: 28).

The Ottomans knew that the Alawites could not resist the Egyptians for a long time without their help. According to a report sent from inside Syria to the Grand Vizier, the Alawites were awaiting the arrival of the Ottoman forces. According to another report sent by the Ottomans to their clients in Syria, they told them that the attack on the Egyptians was postponed until the spring of the next year due to the bad weather conditions in winter. The long preparations of the army also had an impact. Despite this, the Alawites continued their rebellion until the middle of April 1835. The Ottomans did not come to help them (Talhamy, 2011: 30-1).

Despite this, the Ottoman government did not benefit greatly from the Alawite revolt as the Ottomans, under pressure from French diplomacy, abandoned the invasion of Syria. However, after a few years, it returned to Britain's proposals to arm the sects and minorities against Egyptian rule (Winter, 1999: 68).

As a result, the rebellion of the Alawites continued until the middle of April 1835. The Ottomans did not come to help them seriously, nor did they send enough support to strengthen the resistance of the Alawites against Egyptian rule. The result was that after eight months of continuous conflict between the Alawites and 
Egyptians, the Alawites rebellion has been completely eliminated and disarmed. Ibrahim Pasha ordered the arrest of every Alawites rebel in order to control and recruit them into the Egyptian army. An estimated 4000 men were recruited and many were then forced to leave the mountains (Talhamy, 2011: 30-2). In addition to all of this, the Egyptians destroyed their villages, water wells, cut down their fruit trees and engaged in looting (Capar, 2013: 57).

It is difficult to explain the Ottoman Empire's position on the Alawite rebellion. It could have been exploited, armed and supported in order to better help them get rid of the Egyptian rule of Syria. It was a valuable opportunity for the Ottoman Empire that they squandered without achieving any significant result.

\section{The reasons behind the failure of the Alawites rebellion}

The failure of the Ottoman Empire to support the Alawites rebellion was a major reason for the failure of the rebellion itself, along with the differences between the Alawites rebellion in 1834 and the Druze rebellion in 1838 where the Druze rebellion in Horan was organized and led by distinguished leaders. In contrast, the Alawites rebellion did not have a distinguished leadership. This caused the suppression of the rebellion, like the rebellion of the Alawites in 1834 shortly after Ibrahim Pasha defeated the Ottoman forces in Konya and Kütahya. This timing made it was impossible for the Ottoman government to organize any real attack against the Egyptians in support of the rebellion Alawites. Thus the rebellion of the Alawites was only supported morally by the Ottoman Empire and not materially or militarily. It is clear that the timing of the rebellion was one of the reasons for its failure (Talhamy, 2012: 991; Capar, 2013: 58).

\section{The results of the Alawite rebellion}

After eliminating the rebellion of the Alawites, the Druze soldiers returned to Lebanon while the Egyptian soldiers stayed in the Alawites areas until security was absolutely established (Maeruf, 2013, 3: 224). Ibrahim Pasha tried to alleviate his hard policies against the Alawites by appointing the sons of their leaders as officers in the Egyptian army and granting many privileges to their fathers. Nevertheless, the Egyptian army's suppression of the Alawites was still stuck in memories, as the Protestant missionary Samuel Lyde, who traveled to the region in the 1850s, noted 
this and said: "We saw The vast arched cellars that There are still remnants of burning wheat, which attest to the occupation of Ibrahim Pasha's forces" (Capar, 2013: 57).

One of the results of the Alawites rebellion also was that the Alawites warriors who were forced to be recruited into the army of Muhammad Ali Pasha, and who were the cause of his great victories no longer had a seat after the end of the battles in the reconciliation period in 1840. They settled in the Adana region and they were the seed of the Alawite presence in the region, especially since Ibrahim Pasha with his Alawite army had settled in Adana for 6 years (Maeruf, 2013, 3: 230).

After the alliance of European countries with the Ottoman Empire and the withdrawal of the Egyptian forces from Syria in 1840, the Ottomans armed the local population. Ibrahim Pasha warned the Ottoman officials to abandon this policy. Ottoman commander Omar Pasha said: "You, with the assistance of English, have expelled me; you have again put arms into the hands of the mountaineers; it cost me nine years and ninety thousands men to disarm them" (Walpole, 1851, 3: 127; Winter, 1999: 68).

\section{Conclusion}

It is clear from this study that the causes of the Alawite rebellion were mainly social and economic rather than political or sectarian. It is also evident that the Alawite rebellion was not a central rebellion but rather isolated and sporadic that took place over a short period of time. The rebellions took place without any prior coordination, whether at the regional level or at the level of the local leaders. The rebellion did not have a specific leader or influential leaders who brought the Alawites together and unified the rebellion and its goals. This was one of the reasons for the failure of the rebellion as a whole. This study also states that the Ottoman Empire tried to benefit from the rebellion but it did not succeed in doing so. This is because its support was limited to political and moral support only. In the end, the Egyptian authorities managed to achieve their goals by suppressing the rebellion as they imposed compulsory recruitment and disarmed them using military force. 


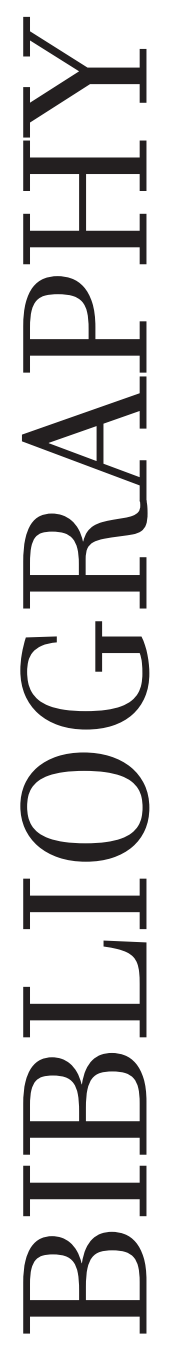

ALKAN, Necati (2012). "Fighting for the NuṢayrī Soul: State, Protestant Missionaries and the 'Alawis in the Late Ottoman Empire". Die Welt des Islam. 2012. 52.

ALTAWIL, Muhammed Amin Ghalib (1924). Tarikh Aleulwiayn. Latakia: Mutbaeat Altarquy (In Arabic).

CAPAR, Ali (May 2013). "The History of Nusayris (Alawis) in Ottoman, Syria, 1831 1876". University of Arkansas Master of Art in History.

DODWELL, Henry (1931). The Founder of Modern Egypt, A Study of Muhammad Ali. Cambridge: At the University Press.

Egyptian National Library and Archives (ENLA), Eabidin Mahfaza (EM) (Eabidin File). File 249-250.

ELLIS, Kail C. (Ed.) (2018). Secular Nationalism and Citizenship in Muslim Countries: Arab Christians in the Levant. London: Palgrave MacMillan.

GRANT, J. A and Temperley, Harold (1948). Europe in the Nineteenth and Twentieth Centuries 1789-1939. London: Longmans, Green and Co.

HATHAWAY, Jane (2008). The Arab Lands under Ottoman Rule 1516-1800. London: Routledge.

KINNEAR, John G (1841). Cairo, Petra, and Damascus, in 1839. With Remarks on the Government of Mehemet Ali, and on the Present Prospects of Syria. London: John Murray.

LANDWEHR, Patrick (2018). "Moving Beyond the Syrian Identity-Based Conflict, Religion, Politics, Conflict and Peace Building, The Changing Alawite Identity from the Ninth Century till 2016”. Rijksuniversiteit Groningen Master Thesis.

MAERUF, Imil Abbas al (2013). Tärìkh al-'Alawìyin fì bilād al-Sbām mundhu fajr

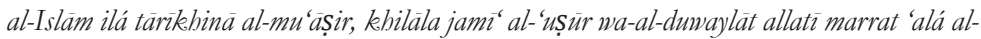
mintaqah al-A Arabiyah al-Islamiyah. Lebanon: Dar al'amal wal salam, 3. (In Arabic).

MAKDISI, Ussama (2000). The Culture of Sectarianism: Community, History and Violence in Nineteenth-Century Ottoman Lebanon. Berkeley - Los Angeles: University of California Press.

MARSOT, Afaf Lutfi Al-Sayyid (1984). Egypt in the Reign of Mubammad Ali. New York: Cambridge University Press.

MOOSA, Matti (1988). Extremist Shiites, The Ghulat Sects. Syracuse: Syracuse University Press.

OLSSON, Tord (1998). "The Gnosis of the Mountaineers and Townspeople. The Religion of Syrian Alawites, or the Nusairis". Alevi Identity: Cultural, Religious and Social Perspectives, in Olsson, Tordand Elisabeth Ozdalga and Catharina Raudvere (Ed.). Istanbul: Swedish Research Institute.

PIPES, Daniel (1990). Greater Syria, The History of an Ambition. Oxford, Oxford University Press.

POUjOUlAT, M (1841). Baptistin, Voyage dans L'asie Mineure, en Mésopotamie, à Palmyre, en Syrie. Paris: Ducollet, 2. 
RUSTUM, Asad (October 1924). "Syria under Muhammad Ali", The American Journal of Semitic Languages and Literatures. 1923. 41/1.

(1941-1943). Al-Mahfuzat Al-Malikiyya Al-Misriyya: Bayan bi wathay'iq al-sham. (Beirut: Matbaeat Al- Jamieat Al-Amirkia, 3. (in Arabic).

SHILLINGTON, Kevin (ed) (2005). Encyclopedia of African History. New York: Fitzroy Dearborn. 1.

SHOUP, John A (2018). The History of Syria. Santa Barbara: ABC-CLIO.

SOWERWINE, James E (2010). Caliph and Caliphate. Oxford: Oxford University Press.

TALHAMY, Yvette (April 2011). "Conscription among the Nusayris ('Alawis) in the Nineteenth Century”. British Journal of Middle Eastern Studies. 2011. 38/1.

(March 2010). "The Fatwas and the Nusayri/Alawis of Syria". Middle Eastern Studies. 2010. 46/2.

(November 2012). "The Nusayri and Druze Minorities in Syria in the Nineteenth Century: The Revolt against the Egyptian Occupation as a Case Study". Middle Eastern Studies. 2012. $48 / 6$.

(2015). "The Alawis in the Ottoman Period", in, Kerr, Michael and Larkin, Craig. The Alawis of Syria, War, Faith and Politics in the Levant. Oxford: Oxford University Press.

(2004). "The Nușayrīs before the Tanzimat in the Eyes of Ottoman Provincial Administrators, 1804-1834", From the Syrian Land to the States of Syria and Lebanon. in Philipp, Thomas and Schumann, Christoph (Ed). Beirut: Orient Institute der DMG Beirut.

(2019). Latakia (al-Lädhiqiyya), Ottoman Period. Encyclopaedia of Islam. 3.

WALPOLE, Frederick (1851). The Ansayrii (or Assassins): With Travels in the Further East. London: Richard Bentley. 3.

WINTER, Michael and Levanoni, Amalia (Ed.) (2004). The Mamluks in Egyptian and Syrian Politics and Society. Leiden: Brill.

WINTER, Stefan (1999). "La Révolte alaouite de 1834 contre l'occupation égyptienne : perceptions alaouites et lecture ottoman". Oriente Moderno. 1999. 79/3.

WORREN, Torstein Schiøtz (February 2007). "Fear and Resistance, The Construction of Alawi Identity in Syria". University of Oslo Department of Sociology and Human Geography Master thesis in Human Geography.

YILMAZ, Hüseyin (2018). Caliphate Redefined: The Mystical Turn in Ottoman Political Thought. Princeton: Princeton University Press. 
Yousef Hussein OMAR

88 Forschungszeitschrift über das Alevitentum und das Bektaschitentum / 2020 / 22 